\title{
Terapi non bedah pada karsinoma sel basal
}

\author{
Adeline Santoso ${ }^{1 *}$, I Gusti Ngurah Darmaputra ${ }^{2}$, Dewi Gotama ${ }^{1}$, Sissy ${ }^{1}$
}

CrossMark

Published by Intisari Sains Medis

${ }^{1}$ Residen Departemen Dermatologi dan Venereologi, Fakultas Kedokteran Universitas Udayana/RSUP Sanglah;

${ }^{2}$ Departemen Dermatologi dan Venereologi, Fakultas Kedokteran Universitas Udayana/RSUP Sanglah;

\section{*Korespondensi:}

Adeline Santoso;

Residen Departemen Dermatologi dan Venereologi, Fakultas Kedokteran Universitas Udayana/RSUP Sanglah;

santosoadeline@gmail.com

Diterima: 07-03-2021

Disetujui: 12-08-2021

Diterbitkan: 31-08-2021

\section{ABSTRACT}

Basal cell carcinoma accounts for approximately $75 \%$ of non-melanoma skin cancer and $25 \%$ of all diagnosed skin cancer in the United States. Epidemiological data show the incidence is increasing significantly by $3 \%$ $-10 \%$ per year worldwide. Changes in life expectancy patterns are associated with an increase in this skin cancer, and the incidence is predicted to increase until 2040. Many factors must be considered in the choice of therapy for a patient, including the patient's general condition, the presence or absence of serious medical

problems, the use of antiplatelet or anticoagulant medication. Conservative treatment of asymptomatic and low-risk lesions is recommended, as overly aggressive therapy may have a greater effect than the lesions themselves. Topical therapy and non-surgical therapy are currently quite effective as therapeutic options for low-risk basal cell carcinoma and highrisk basal cell carcinoma. They can be an option in conditions that are contraindicated for surgery.

Keywords: Basal cell carcinoma, noninvasive treatment, $B C C$, skin cancer.

Cite This Article: Santoso, A., Darmaputra, I.G.N., Gotama, D., Sissy. 2021. Terapi non bedah pada karsinoma sel basal. Intisari Sains Medis 12(2): 723-727. D01: 10.15562/ism.v12i2.995

\section{ABSTRAK}

Kasus keganasan karsinoma sel basal (KSB) mencakup sekitar 75\% dari kasus kanker kulit non melanoma dan mencakup 25\% dari semua kasus kanker yang didiagnosa di Amerika Serikat. Data epidemiologi menunjukkan insiden meningkat signifikan sebanyak 3\%-10\% per tahun di seluruh dunia. Perubahan pola usia harapan hidup berhubungan dengan peningkatan kanker kulit ini, dan di prediksi insiden akan terus meningkat sampai tahun 2040. Terdapat banyak faktor yang harus dipikirkan dalam pemilihan terapi pada pasien, antara lain keadaan umum pasien, ada atau tidaknya masalah medis serius, penggunaan obat anti platelet atau anti koagulan. Perawatan konservatif pada lesi asimptomatik dan beresiko rendah dianjurkan, dikarenakan terapi yang terlalu agresif mungkin akan memberikan efek yang lebih besar dibandingkan dengan lesi itu sendiri. Saat ini terapi topikal dan terapi non-bedah dikatakan cukup efektif sebagai pilihan terapi untuk KSB resiko rendah dan KSB resiko tinggi serta dapat menjadi pilihan pada kondisi kontraindikasi terhadap tindakan pembedahan.

Kata kunci: Karsinoma sel basal, terapi non invasif, KSB, keganasan kulit.

Sitasi Artikel ini: Santoso, A., Darmaputra, I.G.N., Gotama, D., Sissy. 2021. Terapi non bedah pada karsinoma sel basal. Intisari Sains Medis 12(2): 723-727. D0I: 10.15562/ism.v12i2.995

\section{PENDAHULUAN}

Karsinoma sel basal (KSB) merupakan kanker kulit terbanyak pada manusia. ${ }^{1}$ Walaupun kejadian untuk menjadi metastasis jarang terjadi tetapi kejadian morbiditas dikarenakan invasi dan destruksi ke jaringan sekitarnya akan menyebabkan kerusakan struktur anatomi ${ }^{2}$, selain itu KSB juga membutuhkan biaya yang cukup besar dalam proses terapinya. ${ }^{1}$

Karsinoma sel basal banyak ditemukan pada ras kulit putih, seperti di Eropa, Australia, Amerika Serikat menunjukkan jumlah insiden yang terus meningkat dan terutama pada usia lanjut. ${ }^{3,4}$ Faktor risiko yang paling berperan terhadap perkembangan kanker ini adalah paparan radiasi sinar UV dan jenis tipe kulit. ${ }^{5}$ Semakin banyak jumlah pigmen kulit menyebabkan penurunan dari penetrasi sinar UV ke lapisan kulit yang lebih dalam. ${ }^{6}$ Dengan berkurangnya paparan sinar UV maka kerusakan sel basal epidermis berkurang, memungkinkan penurunan tingkat transformasi keganasan. Pada populasi Asia dilaporkan insiden KSB 16 - 20 kasus per 100.000 dan terus menunjukkan peningkatan sejak tahun 1960. Insiden KSB pada ras kulit putih dilaporkan lebih dari 200 kasus per 100.000 pada perempuan dan lebih dari 400 kasus per 100.000 pada laki - laki. Hal ini diduga karena insiden yang lebih jarang pada populasi Asia menyebabkan tenaga kesehatan lengah sehingga pada 
data didapatkan waktu terapi keganasan yang lebih lama pada populasi Asia dibanding ras Kaukasia. ${ }^{6,7}$

Terdapat banyak modalitas terapi yang telah dideskripsikan untuk KSB yang secara umum tujuan terapi adalah untuk mengeradikasi tumor dengan hasil kosmetik yang terbaik. Beberapa modalitas terapi antara lain pembedahan, cryosurgery, curettage, radioterapi, fotodinamik terapi, terapi injeksi intralesi, pengobatan oral, dan terapi topikal. Secara garis besar terapi pada KSB dapat dibagi menjadi terapi bedah dan non bedah. ${ }^{8}$

Beberapa faktor seperti kondisi pasien, kondisi penyakit, pilihan pasien, ketersediaan layanan, pengalaman dan pertimbangan dari dokter ahli mempengaruhi terhadap pemilihan terapi yang akan digunakan., ${ }^{8,9}$ Saat ini terapi topikal dan terapi non-bedah dikatakan cukup efektif sebagai pilihan terapi untuk KSB resiko rendah dan KSB resiko tinggi. ${ }^{9}$ Terapi non bedah juga memberikan hasil kosmetik yang baik dan dapat dipilih jika terdapat kontraindikasi terhadap tindakan pembedahan. ${ }^{1}$ Tujuan tinjauan pustaka ini bertujuan menambah wawasan para klinisi dalam menentukan dan memilih terapi non bedah yang sesuai pada pasien KSB.

\section{TERAPI NON PEMBEDAHAN PADA KARSINOMA SEL BASAL}

Terapi non bedah dapat dijadikan alternatif pilihan terapi dengan hasil terapi dan kosmetik yang baik pada kelompok KSB yang beresiko rendah untuk rekurensi maupun KSB dengan resiko tinggi yang kontraindikasi untuk melakukan tindakan pembedahan, atau karena alasan medis lain. ${ }^{1}$

\section{Terapi Topikal}

\section{Imiquimod}

Imiquimod adalah imidazoquinoline dengan aktivitas antivirus dan antitumor. Obat ini diakui sebagai terapi untuk kutil kelamin, keratosis aktinik, dan KSB superfisial. Mekanisme kerja imiquimod krim 5\% ini dalam terapi KSB belum sepenuhnya dipahami. Beberapa penelitian menyatakan imiquimod memiliki aktivitas antitumor melalui respon target pada sistem imun dan menginduksi apoptosis pada sel KSB sehingga terjadi destruksi tumor. Efek dari imiquimod di mediasi oleh induksi berbagai macam sitokin antara lain interferon- $\alpha$ (IFN- $\alpha$ ), IFN- $\mathrm{\gamma}$, tumor necrosis factor- $\alpha$ (TNF- $\alpha$ ), interleukin (IL)-1 $a$ dan IL-12. Imiquimod memodulasi respon imun innate dengan menstimulasi sel mononuklear ke jaringan KSB. Infiltrasi sel imun dikatakan tidak ada atau hanya sedikit pada tumor KSB dikarenakan rendahnya ekspresi molekul adhesi pada sel tumor sehingga menghambat ikatan dengan sel imun, hal ini yang menyebabkan rendahnya aktifitas cell mediated immune response pada KSB. Sehingga beberapa penelitian mendemonstrasikan penggunaan imiquimod topikal untuk meningkatkan infiltrasi sel imun pada tumor KSB., ${ }^{8,10}$

Penggunaan topikal imiquimod menginduksi produksi sitokin lokal dari keratinosit dan sel lainnya. Imiquimod bekerja secara agonis pada toll like receptor-7 (TLR-7) dan TLR-8 yang memediasi signal kaskade untuk sekresi sitokin proinflamasi seperti IFN- $\alpha$, IFN- $\mathrm{\gamma}$, tumor necrosis factor- $\alpha$, IL-1, IL-1 receptor antagonist, IL-6, IL-10, IL12, granulocyte colony-stimulating factor, granulocyte-monocyte colony-stimulating factor, dan kemokine IL-8, macrophage inflammatory protein $1 \alpha$, dan monocyte chemotactic protein $1 .{ }^{11}$ Imiquimod juga menstimulasi respon imun innate dengan meningkatkan aktifitas NK sel, makrofag, dan sel Langerhans dan menginduksi proliferasi dan maturasi sel-B limfosit. Selain itu imiquimod juga memiliki aktifitas proapoptosis langsung pada sel tumor. ${ }^{11}$ Imiquimod juga menginduksi down regulasi gen onkogenesis Patched, GLI1, GLI3 yang berperan dalam patogenesis KSB. ${ }^{10}$

Dosis aplikasi 5 kali per minggu selama 6 minggu, sebanyak $90 \%$ pasien mengalami clinical clearance dalam 12 minggu setelah terapi. ${ }^{12}$ Durasi terapi bervariasi 6-16 minggu. Untuk KSB superfisial tingkat kesembuhan $70-100 \%$, dengan dosis terapi 5 kali per minggu selama 6 minggu. Dapat digunakan pada KSB nodular dengan tingkat kesembuhan lebih rendah dibandingkan KSB superfisial. Berdasarkan data yang telah ada, dikatakan imiquimod topikal dapat mengatasi KSB superfisial, walaupun data 5 tahun follow up masih diperlukan lebih banyak untuk menilai terapi lebih lanjut. Sedangkan imiquimod pada KSB nodular masih belum jelas, karena belum banyak dilakukan penelitian dan follow up. ${ }^{4}$

Reaksi pada lokasi aplikasi banyak dilaporkan dan insiden meningkat dengan semakin meningkatnya frekuensi aplikasi. Dilaporkan reaksi yang sering terjadi dengan aplikasi imiquimod 5 dan 7 kali per minggu selama 6 minggu adalah gatal (16\% dan 26\%), rasa terbakar (6\% dan $9 \%)$, nyeri (3\% dan 6\%). Reaksi kulit lokal seperti eritema, edema, vesikel, erosi, krusta terjadi lebih sering pada aplikasi Imiquimod 7 kali per minggu. Tujuh belas reaksi sistemik dilaporkan $<3 \%$ kasus dengan gejala nyeri otot, malaise, demam, nyeri kepala. ${ }^{13}$

Topikal imiquimod diindikasikan untuk individu dengan KSB superfisial dengan ukuran tumor $<2 \mathrm{~cm}$ pada lokasi yang sulit untuk dioperasi. Walaupun terapi pembedahan memiliki tingkat untuk terjadinya rekurensi yang lebih baik namun tidak selalu dapat dilakukan, terutama pada orang tua dengan banyak faktor komorbiditas, pada lokasi yang sulit, dan pasien tidak menginginkan tindakan pembedahan. Topikal imiquimod dapat dijadikan pilihan terapi yang non invasif, aman, efektif untuk dijadikan alternatif pilihan terapi. ${ }^{12,14}$

\section{5-Fluorouracil (5-FU)}

5-Fluorourasil (5-FU), suatu agen kemoterapi topikal yang digunakan dalam mengobati keratosis aktinik, juga telah digunakan dalam mengobati KSB. ${ }^{11}$ Mekanisme kerja dari 5-FU topikal sebagai terapi keganasan kulit hampir sama dengan 5-FU yang diaplikasikan secara intravena yang telah banyak digunakan untuk terapi kanker organ dalam (kanker payudara, kolon, pancreas, dil). 5-FU mengganggu sintesis DNA dengan menghambat metilasi dari asam deoxyuridylic dan menghambat sintesis thymidylate yang kemudian menghambat proliferasi sel. ${ }^{15}$

U.S. Food and Drug Administration menyatakan rekomendasi dosis untuk KSB superfisial dengan aplikasi dilakukan secara tipis - tipis 2 kali sehari selama 3-6 minggu. Pemberian terapi ini dapat diaplikasikan sampai 1-2 mm disekitar kulit sehat dan didiamkan selama 10- 
14 jam. $^{15}$ Total area kulit yang dapat diberikan 5-FU dalam satu kali terapi adalah tidak melebihi $500 \mathrm{~cm}^{2}$ atau $23 \times 23$ $\mathrm{cm} .{ }^{12}$ Area yang luas dapat diterapi secara bergantian pada waktu selanjutnya. Pada minggu keenam dilakukan evaluasi terapi melalui penampakan klinis, jika masih terdapat sisa tumor maka terapi dapat dilanjutkan sampai maksimal 12 minggu. ${ }^{15}$ Terapi oklusi akan meningkatkan reaksi inflamasi pada kulit. Respon yang dapat terjadi setelah aplikasi 5-FU topikal antara lain, eritema yang akan memburuk menjadi kehitaman atau nekrosis, kemudian akan menyembuh. Selain itu dapat menyebabkan nyeri, bula, dan ulkus kulit. $^{12}$

\section{Terapi Fotodinamik}

Terapi fotodinamik meliputi aktivasi suatu obat yang berperan sebagai agen fotosensitizer yang diaktivasi oleh cahaya kasat mata (visible light) yang menghasilkan spesies oksigen teraktivasi yang kemudian menghancurkan sel-sel kanker. ${ }^{11}$ Fotosensitizer adalah molekul dengan berat molekul rendah, larut air dan di administrasikan secara topikal pada permukaan kulit. Salah satu produk fotosensitizer yang dipakai adalah aminolevulinic acid (ALA) dan methylaminolevulinate (MAL).

Mekanisme kerja fotodinamik terapi bergantung dari jaringan target, fotosensitizer, cara penggunaan dan dosis yang diaplikasikan. Ketika ALA atau MAL topikal diaplikasikan pada tumor kulit seperti KSB dan berdifusi pada stratum korneum ke dalam epitel sel target. Oksigen dihantarkan melalui sirkulasi. ALA dan MAL terkonversi menjadi protoporphyrin IX (PpIX) di mitokondria setelah radiasi oleh cahaya fotoaktif. PpIX akan keluar dari mitokondria kemudian mendistribusikan konsentrasi fotosensitizer ke dalam sel endothelial yang berdifusi ke sel target. Selama fase kerusakan fotodinamik akut, plasma dan membran nukleus kehilangan integritasnya, sel endotel terjadi formasi thrombus dan kolaps pembuluh darah, terjadi penghentian aliran darah dan menyebabkan apoptosis serta nekrosis jaringan. ${ }^{16}$

Keuntungan dari fotodinamik terapi adalah sifatnya yang kurang toksik dan cukup aman digunakan. Salah satu efek yang dirasakan saat terapi adalah nyeri, hal ini bisa menyebabkan pasien tidak tuntas menajalankan terapi. ${ }^{17}$ Dikatakan MAL/ PDT memiliki skala nyeri lebih rendah dibanding ALA/PDT. Fotodinamik terapi dapat digunakan pada pasien dengan banyak komorbiditas. Efek samping lainnya berupa edema, eritema, rasa seperti ditusuk-tusuk, bengkak yang akan berangsur menghilang. Hipopigmentasi dan hiperpigmentasi dapat terjadi pada $5 \%$ kasus, dermatitis kontak alergi walaupun jarang terjadi juga dilaporkan pada beberapa pasien. ${ }^{17}$ Terapi nya dapat dilakukan pengulangan dengan efek samping jangka panjang yang minimal. ${ }^{16}$

\section{Terapi intralesi}

Interferon alfa-2b (Intron A)

Beberapa penelitian menyebutkan interferon menjadi terapi yang efektif untuk KSB. Penggunaan interferon alpha-2b selama 3 minggu memberikan keberhasilan terapi 70-100\%. Mekanisme interferon menghasilkan regresi pada sel KSB belum jelas. Interferon merupakan kelompok glikoprotein alami yang memiliki banyak fungsi biologis antara lain mengatur pertumbuhan dan diferensiasi sel, meregulasi antigen permukaan sel, memodulasi respon imun seluler dan humoral. Terjadi peningkatan CD4+ sel $T$ pada dermis dan sarangsarang KSB setelah terapi intralesi interferon mengindikasikan sel T memacu sel imun melawan tumor. Sel T CD4+ dan sel T CD8+ akan mengekspresikan aktivitas sitolitik terhadap sel tumor dan menginduksi terjadinya apoptosis. Sel T CD4+ sitotoksik mampu mennginduksi apoptosis melalui interaksi reseptor CD95 - CD95 ligand. ${ }^{1,18,19}$ Efek samping yang biasa terjadi paska terapi antara lain reaksi hipersensitifitas $(<5 \%)$, menggigil (40-65\%), demam (40-90\%), lemas (50$90 \%)$, penurunan berat badan (25\%), mual muntah (20-50\%), pusing (20-70\%), nyeri otot (30-75\%), seperti gejala flu like syndrome pada sebagian besar pasien. ${ }^{1}$

\section{Interferons Alpha-2b dan Gamma}

Pada penelitian sebelumnya dikatakan interferon tidak efektif untuk terapi KSB yang agresif. Interferon sendiri atau kombinasi dengan retinoid dikatakan gagal sebagai terapi kanker kulit non melanoma yang agresif. Kombinasi terapi interferon sebagai terapi kanker yaitu Heberpag yaitu kombinasi antiproliferasi yang bekerja sinergis memiliki formula interferons alpha-2b dan gamma, natrium fosfat hydrogen, natrium klorida, albumin. Injeksi dilakukan 3 kali seminggu selama 3 minggu, injeksi 3.5 MIU untuk tumor < $4 \mathrm{~cm}$ dan 10.5 MIU untuk tumor $>4 \mathrm{~cm}$ yang diinjeksikan pada area $1,5 \mathrm{~cm}^{2}$, dosis besar sampai 21 MIU dapat diberikan pada kasus KSB dengan resiko tinggi atau KSB rekuren yang sudah di terapi sebelumnya dengan radioterapi. ${ }^{19,20}$

Efek samping diamati pada $86 \%$ pasien pada 58 kejadian yang berbeda, yang tersering demam (64\%), menggigil (49\%), nyeri otot $(35 \%)$, pusing $(32 \%)$, edema dan eritema pada lesi injeksi, dermatitis kontak alergi dan fotosensitisasi lokal pada daerah aplikasi dapat terjadi. ${ }^{20,21}$

\section{Terapi Oral \\ Hedgehog Pathway inhibitor}

Berdasarkan temuan bahwa terjadi peningkatan aktivitas hedgehog $(\mathrm{HH})$ pada KSB maka selanjutnya dikembangkanlah $\mathrm{HH}$ inhibitor (HHI) sebagai suatu modalitas terapi terhadap KSB metastatik atau KSB agresif lokal. Bahan HHI yang telah dikenal baik ialah suatu alkaloid yang berasal dari tumbuh-tumbuhan (plant alkaloid) yaitu siklopamin. Siklopamin bekerja secara kompetitif dalam menghambat protein smoothened (SMO) signaling dan karenanya menghambat pertumbuhan sel-sel malignan yang berasal dari aktivasi $\mathrm{HH} .{ }^{11}$

Vismodegib merupakan terapi HHI pertama yang disetujui untuk KSB metastasis (mKSB) dan KSB lokal advanced (laKSB) yang tidak dapat dioperasi atau diradiasi, atau rekurensi paska operasi. laKSB termasuk tumor primer yang menginvasi dan meluas di kulit, kartilago, otot, tulang atau terjadi metastasis pada kelenjar getah bening. Pada metastasis KSB penyebaran jauh ke organ atau kelenjar getah bening non regional. Vismodegib adalah obat pertama di kelas penghambat molekul dari SMO yang secara selektif menghambat jalur $\mathrm{HH}$ dengan berikatan pada SMO, sehingga menghambat signal menyimpang dari jalur HH. Pada tahun 2009 penelitian 
menunjukkan respon terapi 58\% pada pasien mKSB dan laKSB. Dosis rekomendasi vismodegib $150 \mathrm{mg}$ per hari sampai membaik atau efek samping tidak dapat ditolerir. Obat ini memiliki efek samping kematian fetus atau kecacatan saat dilahirkan, sehingga kehamilan harus di atur jika menggunakan terapi ini., ${ }^{5,22}$

Sonidegib adalah antagonis SMO selektif yang poten dengan penetrasi jaringan yang tinggi. Dosis yang direkomendasikan $200 \mathrm{mg}$ per hari yang dikonsumsi saat perut kosong atau 2 jam setelah makan atau 1 jam sebelum makan. Terapi digunakan sampai terjadi perbaikan penyakit atau sampai terjadi toksisitas yang tidak dapat ditangani. Modifikasi dosis dilakukan jika terjadi peningkatan creatinine phosphokinase (CK) atau terjadi efek samping pada otot, maka dosis $200 \mathrm{mg}$ diberikan secara berselang hari atau dihentikan. Tidak disarankan pula diberikan pada ibu yang sedang menyusui karena obat dapat larut dalam air susu ibu (ASI) dan menyebabkan efek samping serius. Efek samping dapat terjadi pada $20 \%$ kasus, antara lain kram otot (68\%), kebotakan (63\%), dysgeusia (51\%), penurunan berat badan (46\%), lemas (36\%), mual (29\%), diare (22\%), penurunan nafsu makan (23\%). ${ }^{1,22,23}$

\section{Radioterapi}

Terapi radiasi berguna pada kasus KSB primer, KSB rekuren atau pada kasus-kasus margin paska pembedahan menunjukkan hasil positif adanya sel kanker ${ }^{10}$, pada orang tua dengan banyak faktor komorbiditas, kontraindikasi untuk pembedahan, lokasi sulit misal pada kepala, wajah, leher dan ukuran yang besar, keterlibatan perineural. Kelebihan metode ini antara lain ialah ketidaknyamanan minimal serta sifatnya yang tidak invasif sehingga cocok bagi pasien yang tidak mau atau tidak dapat menjalani pembedahan. ${ }^{1,4,22,24}$

Kekurangan metode ini meliputi tidak dapat dilakukannya verifikasi histologis pada tumor yang diangkat, waktu terapi yang panjang, hasil yang secara kosmetik dapat memburuk seiring dengan berjalannya waktu (atrofi kutis dan telangiektasis) serta predisposisi terhadap rekurensi agresif dan ekstensif. ${ }^{11}$
Radioterapi dikontraindikasikan pada terapi ulangan KSB yang kambuh dengan terapi radioterapi sebelumnya. Radioterapi juga dapat menimbulkan pertumbuhan tumor baru pada penderita Basal Cell Nevoid Syndrome sehingga harus dihindari penggunaannya pada kelompok penderita ini. ${ }^{4,8,16}$

Angka keberhasilan sebesar 93\% - 97\% meskipun secara kosmetik radioterapi memberikan hasil yang inferior dari pembedahan. Sebuah pustaka dari Cochrane menemukan bahwa pembedahan dan radioterapi merupakan dua metode terapi KSB yang paling efektif dengan hasil terbaik yang diperoleh melalui pembedahan. ${ }^{11}$

\section{SIMPULAN}

Banyak terapi pilihan yang dapat digunakan untuk KSB. Pertimbangan kondisi pasien, kondisi penyakit, pilihan pasien, ketersediaan layanan, pengalaman dan pertimbangan dari dokter ahli mempengaruhi terhadap pemilihan terapi yang akan digunakan. Pemilihan ini dapat dilakukan dengan mempertimbangkan faktor-faktor prognosis dari pasien.

Secara garis besar penatalaksanaan KSB dibagi menjadi terapi bedah dan non bedah. Terapi bedah dibagi menjadi bedah eksisi dan destruksi. Terapi non bedah dapat dijadikan alternatif pilihan terapi dengan hasil terapi dan kosmetik yang baik pada kelompok KSB yang beresiko rendah untuk rekurensi maupun KSB dengan resiko tinggi yang kontraindikasi untuk melakukan tindakan pembedahan, atau karena alasan medis lain.

\section{KONFLIK KEPENTINGAN}

Penulis menyatakan tidak ada konflik kepentingan terhadap publikasi nashkah ini.

\section{KONTRIBUSI PENULIS}

Seluruh penulis berkontribusi terhadap pencarian referensi, penyusunan naskah publikasi dan publikasi.

\section{PENDANAAN}

Tidak ada.

\section{DAFTAR PUSTAKA}

1. Ariza S, Espinosa S, Naranjo M. Nonsurgical Therapies for Basal Cell Carcinoma: A Review. Actas Dermosifiliogr. 2017;108(9):809-17.

2. Marzuka AG, Book SE. Basal cell carcinoma: Pathogenesis, epidemiology, clinical features, diagnosis, histopathology, and management. Yale J Biol Med. 2015;88(2):167-79.

3. Akdeniz M, Hahnel E, Ulrich C, Blume-Peytavi U, Kottner J. Prevalence and associated factors of skin cancer in aged nursing home residents: A multicenter prevalence study. PLoS One. 2019;14(7):1-11.

4. Bichakjian C, Armstrong A, Baum C, Bordeaux JS, Brown M, Busam KJ, et al. Guidelines of care for the management of basal cell carcinoma. J Am Acad Dermatol. 2018;78(3):540-59.

5. Dika E, Scarfi F, Ferracin M, Broseghini E, Marcelli E, Bortolani B, et al. Basal cell carcinoma: A comprehensive review. Int J Mol Sci. 2020;21(15):1-11.

6. Moore MG, Bennett RG. Basal Cell Carcinoma in Asians: A Retrospective Analysis of Ten Patients. J Skin Cancer. 2012;2012:1-5.

7. Oh CM, Cho H, Won YJ, Kong HJ, Roh YH, Jeong $\mathrm{KH}$, et al. Nationwide trends in the incidence of melanoma and non-melanoma skin cancers from 1999 to 2014 in south korea. Cancer Res Treat. 2018;50(3):729-37.

8. Thomson J, Hogan S, Leonardi-Bee J, Williams HC, Bath-Hextall FJ. Interventions for basal cell carcinoma of the skin. Cochrane Database Syst Rev. 2020;2020(11).

9. Kim DP, Kus KJB, Ruiz E. Basal Cell Carcinoma Review. Hematol Oncol Clin North Am. 2019;33(1):13-24.

10. Fiona B-H, Perkins W. Basal cell carcinoma. In: Williams $\mathrm{H}$, editor. Evidence Based Dermatology, 2nd ed. New Jersey: John Wiley \& Sons; 2008. p. 256-71.

11. Tang J, Epstein E, Oro A. Basal cell carcinoma and Basal Cell Nevus Syndrome. In: Kang S, Amagai M, Brucker A, Enk A, Margolis D, McMichael A, et al., editors. Fitzpatrick's Dermatology in General Medicine, 9th ed. 2019. p. 1884-900.

12. Lanoue J, Goldenberg G. Basal Cell Carcinoma. Clin Ophthalmic Oncol. 2016;9(5):26-36.

13. Bostanci S, Kocyigit P, Vural S, Heper AO, Botsali A. Long-Term Follow-Up Results of Topical Imiquimod Treatment in Basal Cell Carcinoma. Dermatol Surg. 2018;44(1):36-41.

14. Singal A, Daulatabad D, Pandhi D, Arora V. Facial Basal Cell Carcinoma Treated with Topical 5\% Imiquimod Cream with Dermoscopic Evaluation. J Cutan Aesthet Surg. 2016;9(2):122.

15. Soong LC, Keeling CP. Cryosurgery $+5 \%$ 5-fluorouracil for treatment of superficial basal cell carcinoma and bowen's disease. J Cutan Med Surg. 2018;22(4):400-4.

16. Dos Santos AF, De Almeida DRQ, Terra LF, Baptista MS, Labriola L. Photodynamic therapy in cancer treatment - an update review. J Cancer Metastasis Treat. 2019;2019.

17. Cohen DK, Lee PK. Photodynamic therapy for non-melanoma skin cancers. Cancers (Basel). 2016;8(10). 
18. Darmaputra IGN, Wardhana M, Adhilaksman IGN, Indira IGAAE, Suryawati N. Karsinoma sel basal tipe nodular yang diterapi dengan bedah eksisi elips dan anastesi tumesen. Intisari Sains Medis. 2019;10(1):192-6.

19. Gonzalez LGV. Carcinoma basocelular. Tratamiento con interferon alfa $2 \mathrm{~b}$ intralesional. Dermatologia Cosmet Medica y Quir. 2016;14(2):100-5.

20. Fernández-Martori M, Bello-Rivero I, DuncanRoberts Y. Treatment of basal cell carcinoma with interferons alpha- $2 \mathrm{~b}$ and gamma in primary care. MEDICC Rev. 2018;20(1):11-7.
21. Fania L, Didona D, Di Pietro FR, Verkhovskaia S, Morese R, Paolino G, et al. Cutaneous squamous cell carcinoma: From pathophysiology to novel therapeutic approaches. Biomedicines. 2021;9(2):1-33.

22. Fecher LA, Sharfman WH. Advanced basal cell carcinoma, the hedgehog pathway, and treatment options - Role of smoothened inhibitors. Biol Targets Ther. 2015;9:129-40.

23. Silapunt S, Chen L, Migden MR. Hedgehog pathway inhibition in advanced basal cell carcinoma: Latest evidence and clinical usefulness. Ther Adv Med Oncol. 2016;8(5):375-82.

24. Bello Rivero I. HeberFERON, a promising choice for the treatment of basal cell carcinoma. Integr Cancer Sci Ther. 2018;5(5):1-2.

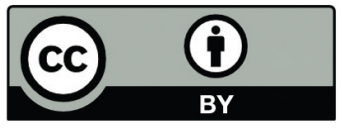

This work is licensed under a Creative Commons Attribution 